Schulich School of Law, Dalhousie University

Schulich Law Scholars

Articles, Book Chapters, \& Blogs

Faculty Scholarship

3-14-2018

\title{
Informal networks of corruption: assessing the challenges for public sector whistleblowing in Nigeria
}

Olabisi Akinkugbe

Dalhousie University Schulich School of Law

Follow this and additional works at: https://digitalcommons.schulichlaw.dal.ca/scholarly_works

Part of the Law Commons

\section{Recommended Citation}

Olabisi D Akinkugbe, "Informal networks of corruption: assessing the challenges for public sector whistleblowing in Nigeria" (2018) 9:1 Jindal Global Law Review 11.

This Article is brought to you for free and open access by the Faculty Scholarship at Schulich Law Scholars. It has been accepted for inclusion in Articles, Book Chapters, \& Blogs by an authorized administrator of Schulich Law Scholars. For more information, please contact hannah.steeves@dal.ca. 


\title{
Informal Networks of Corruption: Assessing the Challenges for Public Sector Whistleblowing in Nigeria
}

\author{
Olabisi D. Akinkugbe*
}

\begin{abstract}
Recently, the Nigerian government adopted its first National Anti-Corruption Strategy - the first since independence in 1960. While the strategy captures varying forms of corruption, whistleblowing is one of the key strategies identified to confront anti-corruption in the public sector. The adoption of the whistleblowing policy and its on-going implementation however occurs without a whistleblowing protection legislative framework. This article situates the whistleblower program in the wider socio-political context of anti-corruption in Nigeria, and public governance in particular. The article critically examines the implications of the whistleblower protection legislative gap for the long-term sustenance of the program. I argue that the whistleblowing program is embedded in the wider socio-political and informal social norms that have historically privileged corruption in Nigeria. To enhance the overall effectiveness and institutionalization of the whistleblowing program in Nigeria, I contend that the urgent adoption of a comprehensive legislative protection framework is a minimum requirement while significant but practical steps must be taken to address the complex background of informal social networks of corruption, power dynamics, and social norms that are peculiar to the Nigerian economic and political context.
\end{abstract}

\section{Introduction}

Although formal anti-corruption graft has a long history in Nigeria, the ineffectiveness of conventional interventions abound as corruption continues minimally abated. ${ }^{1}$ Recently,

\footnotetext{
* Visiting Assistant Professor, Schulich School of Law, Dalhousie University, Halifax, N.S., Canada. Ph.D., (University of Ottawa); LLM (University of Toronto), LLB (Hons) (University of Lagos, Nigeria), BL (Hons) (Nigerian Law School, Abuja); email: olabisi.akinkugbe@dal.ca. An earlier version of this paper was presented as "Towards a Transformative Public Institutional Governance: Whistleblowing and the Perils of Embedded Corruption in Nigeria" at the "Towards New Governance Strategies for Preventing Corruption: Law, Theory and Practice" Conference, Osgoode Professional Development Center, September 14-15 2017, Toronto, Canada.

${ }^{1}$ See, Transparency International, "Corruption Perception Index 2016", $25^{\text {th }}$ January 2017, online: https://www.transparency.org/news/feature/corruption_perceptions_index_2016; also see, The World Justice Project (WJP) Rule of Law Index 2017, https://worldjusticeproject.org/our-work/wjp-rule-lawindex/wjp-rule-law-index-2017-2018; See generally, Femi Falana, "Why the Nigerian Government is Losing Corruption Cases", April 15, 2017, online: http://opinion.premiumtimesng.com/2017/04/15/whygovernment-loses-corruption-cases-by-femi-falana/ (decrying the lethargy in the prosecution of anticorruption cases and the recent rise in the number cases lost by the government, Falana "predict[ed] that the federal government stands to lose more corruption cases unless the authorities are prepared to reorganise the anti-graft agencies and review the anti-corruption policy in line with the proposals designed by the
} 
the Nigerian government introduced whistleblowing as a part of anti-corruption strategy in Nigeria. In particular, on December 21 2016, the Nigerian Federal Ministry of Finance launched the country's first public governance whistleblowing program. With the overall aim of "improving public institutional governance", the Federal Ministry of Finance Whistleblowing program is designed to "encourage anyone with information about a violation of financial regulations, mismanagement of public funds and assets, financial malpractice, fraud and theft to report it.",2

Since the launch of the program, the Nigerian government has also adopted the country's first National Anti-Corruption Strategy (2017-2020) ("NACS"). ${ }^{3}$ NACS is the first anticorruption strategy that any Nigerian government had adopted since its independence in 1960. It echoes the Federal Government's commitment to whistleblowing as a focal point of its anti-corruption campaign. Among other mechanisms, the NACS calls for the introduction and adoption of whistleblower programs and a multi-sectoral engagement of actors that include citizens, faith institutions ${ }^{4}$ and non-governmental organizations in the fight against corruption. The NACS is broad and designed as a policy document to guide intervention at the legal, policy, technical and institutional levels within the public and private sectors. Although commendable, the NACS acknowledges the fact that the factors that sustain corruption in Nigeria are multifaceted, complex, and intertwined and cut across, informal social networks, collective action, and institutional practices that are embedded in the socio-economic, and political relations of everyday living.

This article situates the whistleblower program in the wider informal social networks and norms of corruption and anti-corruption complexity in Nigeria. In this regard, the aims

Presidential Advisory Committee Against Corruption (PACAC) on the prosecution of politically exposed persons.")

${ }^{2}$ See, Federal Government of Nigeria, Federal Ministry of Finance - Whistle Blowing (FAQs), p. 2. online: https://whistle.finance.gov.ng/ catalogs/masterpage/MOFWhistle/assets/FMF\%20WHISTLEBLOWING\% 20FREQUENTLY\%20ASKED\%20QUESTIONS.pdf If an informant has evidence to support his or her disclosure, it must be submitted either via the portal or in writing to the special unit of the ministry. Examples of "information" that may be provided include violation of government's financial regulations, mismanagement or misappropriation of public funds and assets, concealed and stolen public funds, financial malpractice or fraud, theft, collection or solicitation of brides, diversion/underreporting of revenues, conversion of public funds for private use, splitting of contracts, violation of procurement procedures and procurement fraud.; also see generally, Federal Ministry of Finance Whistleblowing Portal: http://whistle.finance.gov.ng/Pages/default.aspx

${ }^{3}$ Nigerian Federal Ministry of Justice, "National Anti-Corruption Strategy - 2017-2020", Final Version, February 10, 2017. (Copy available on file with the author). Also see, Dr. Fatima Waziri - Azi, "An Evaluation of the Nigeria National Anti-Corruption Strategy", (2017) 5:5 European Journal of Research in Social Sciences, pp. 1-9; Frank Eleanya, "FG adopts 5 year national anti-corruption strategy", Business Day Newspapers, April 27, 2017, online: http://www.businessdayonline.com/fg-adopts-5-year-nationalanti-corruption-strategy/; Premium Times Editorial, "Building the Critical Mass for the National AntiCorruption Strategy", Premium Times, May 15, 2017. Online: http://www.premiumtimesng.com/opinion/editorial/231250-editorial-building-the-critical-mass-for-thenational-anti-corruption-strategy.html

${ }^{4}$ On the potential role of faith organizations in anti-corruption graft in Nigeria, see, Olusegun Obasanjo (former President of Nigeria), "The Role of the Church In the Fight Against Corruption In Nigeria", Premium Times Newspapers, Opinion Piece, April 8, 2017; online: https://opinion.premiumtimesng.com/2017/04/08/the-role-of-the-church-in-the-fight-against-corruption-innigeria-by-olusegun-obasanjo/ 
are two-fold. The first is a critical analysis of the current practice of whistleblowing program in Nigeria. In this regard, despite the modest success of the program, ${ }^{5}$ I contend that the existing gap in whistleblower protection law does not bode well for the long-term institutionalization of the program. While I suggest that the Nigerian government must urgently adopt a comprehensive law that accords with international best practices for the protection of whistleblowers, I conceptualize the adoption of such a legislative framework as the minimum threshold for not only the protection of whistleblowers against retaliation and chilling effect, but also, encouraging meaningful overall practice of disclosure of useful information. As the implementation of such a law would be embedded in the broader contexts of anti-corruption graft in Nigeria, I advocate for a context-based solution that not only takes account of but also addresses informal norms and factors that have encouraged corruption beyond the formal frameworks. Having situated the whistleblowing program in the complex socio-economic and political context in Nigeria, the second aim of the article is to analyze some of the critical informal anticorruption norms, values and practices that have undermined the formal anti-corruption measures. Addressing the host of informal norms, values and practices would be key in order to achieve effectiveness of the formal whistleblowing program. In this regard, I posit that a commitment to the formal structure must be simultaneously complemented by informal norms and values of anti-corruption, if the whistleblowing program is to avoid the fate of similar past efforts.

Corruption, which successful whistleblowing may uncover, is not only an economic phenomenon, but also, a moral one which simultaneously influences the socio-cultural norms and institutions of society on the one hand, as well as the political and legal institutions on the other hand. ${ }^{6}$ Its discourse ${ }^{7}$ has impact not only on the formal state structures $^{8}$, but also, on informal socio-political and economic relations and frameworks of governance within a state. Hence, one of the challenges of prior formal anti-corruption legal frameworks and purely legalistic analysis of corruption is that not enough scholarly analysis has focused on the fact that corruption is embedded in a wider complex of both formal and informal social, economic, and political interactions. To be effective, anticorruption mechanisms, must therefore straddle both the formal and informal aspects of corruption. To simply suggest that the non-enforcement of laws or selective implementation of anti-corruption laws is the primary rationale for the continued prevalence of corruption in public governance does not capture the entire narrative of the enmeshment of corruption in the informal social networks that makes it thrive. While the

\footnotetext{
${ }^{5}$ Vanguard Newspaper Press Release, "Whistleblower Policy: A Successful FG's Initiative, says Adeosun", August 15, 2017; online: https://www.vanguardngr.com/2017/08/whistleblower-policysuccessful-fgs-initiative-says-adeosun/

${ }^{6}$ See, Judge, W. Q., McNatt, D. B. \& Xu, W., "The antecedents and effects of national corruption: A metaanalysis" (2011) 1:46 Journal of World Business, pp. 93-103, p. 94.

7 "Discourse" is used here in the Foucaultian context to describe the variety of ways of the representation of corruption as a social reality. See, Akhil Gupta, "Blurred Boundaries: The Discourse of Corruption, the Culture of Politics, and the Imagined State", (1995) 22:2 American Ethnologist pp. 375-402.

${ }^{8}$ Balakrishnan Rajagopal, "Corruption, Legitimacy and Human Rights: The Dialectic of the Relationship", (1999) 14 Conn. J. Int'l L., pp. 495-507. (Deploying what he describes as a "critical development theory", Rajagopal argues that "corruption discourse performs the task of re-legitimating particular conceptions of development, rule of law, democracy and human rights that are elitist, statist and Eurocentric), p. 496.
} 
effective prosecution of corruption cases may be helpful, I contend that the informal mechanisms advanced in this article provide a necessary and complimentary intervention from below. This article therefore contributes to the contemporary and growing academic and policy inquiries that call for conceptualizing discourses around corruption beyond purely legal frameworks by incorporating context-based solutions that include informal strategies as a necessary and critical complementary component of addressing corruption in Nigeria. ${ }^{9}$

\section{Part I}

\section{The Federal Ministry of Finance's Whistleblowing Program}

Generally, whistleblowing refers to the public interest disclosure of information by members of an organization or government employees about illegal and immoral practices by other employees or other persons who deal with the organization, such as contractors, in the case of public governance. ${ }^{10}$

Since the Federal Ministry of Finance Whistleblowing Program ("FMF-Whistle Program"), is designed to "encourage anyone with information about a violation of financial regulations, mismanagement of public funds and assets, financial malpractice, fraud and theft to report it," 11 whistleblowers in Nigeria go beyond the employee/employer and public/private sector dichotomies. Any stakeholder (whether internal or external) with valuable information is encouraged to provide useful information in the public interest using an officially provided channel. ${ }^{12}$

As a public governance integrity enhancing mechanism, whistleblowing in Nigeria is also linked to encouraging and enhancing the public disclosure of wrongdoing in order to

\footnotetext{
${ }^{9}$ See generally, Leena Koni Hoffmann and Raj Navanit Patel, "Collective Action on Corruption in Nigeria: A Social Norms Approach to Connecting Society and Institutions", Chatham House Report, The Royal Institute of International Affairs, pp. 1-53, p. 5, May 2017. The report which a social norms approach to anti-corruption in Nigeria is based on field research undertaking in Nigeria from October to November 2015 and for 4 months in 2016. The survey was conducted in urban and rural areas in sex states: Adamawa, Benue, Enugu, Lagos, Rivers and Sokoto; and in the Federal Capital Territory of Abuja. Also, "the report proposes the integration of behavioral lessons in anti-corruption policymaking, and advocates strategies for expanding Nigeria's knowledge base and capacity concerning behavior and social norms-based interventions and solutions." In the context of other countries in Africa and beyond, see, Claudia BaezCamargo and Alena Ledeneva, "Where Does Informality Stop and Corruption Begin? Informal Governance and the Public/Private Crossover in Mexico, Russia and Tanzania", (2017) Vol. 95, No. 1, The Slavonic and East European Review, (Innovations in Corruption Studies), pp. 49-75.

${ }^{10}$ See generally, A. J. Brown, (eds.). Whistleblowing in the Australian Public Sector: Enhancing the theory and practice of internal witness management in public sector organisations, (The Australian National University E Press; 2008), p. xxi; Near, J. P., \& Miceli, M. P., "Organizational dissidence: The case of whistle-blowing" (1985) 4 Journal of Business Ethics, pp. 1-16; Near, J. P., \& Miceli, M. P., "Whistleblowing: Myth and reality", (1996) 22:3, Journal of Management, pp. 507-526.

${ }^{11}$ See, Federal Government of Nigeria, Federal Ministry of Finance - Whistle Blowing (FAQs), p. 2.

${ }^{12}$ In relation to the FMF-Whistle Program, see, "Federal Ministry of Finance Whistleblowing Portal"; online: http://whistle.finance.gov.ng/Pages/default.aspx
} 
improve accountability and transparency. ${ }^{13}$ The categories of information that a whistleblower can provide under the FMF-Whistle Program include but are not limited to the violation of government's financial regulations; mismanagement or misappropriation of public funds and assets; information on stolen public funds or concealed public funds; financial malpractice or fraud; theft, collecting/soliciting brides; diversion of revenues; conversion of public funds for personal use; and splitting of contracts. ${ }^{14}$ The FMFWhistle Program specifically excludes personal grievances that arise from private contracts. $^{15}$

Under the FMF-Whistle Program, whistleblowers can disclose information anonymously and guarantees confidentiality to "the extent possible within the limitations of the law.""16 It is sufficient that the whistleblower holds a reasonable belief that the information provided is true. The information provided by the whistleblower would be examined by the administrators of the Federal Ministry of Finance's whistleblowing portal or the staff to whom it is assigned who make the preliminary analysis on whether to open an investigation into the matter reported.

An internal or external whistleblower that suffers adverse treatment - such as harassment, intimidation or victimization - in retaliation is encouraged to "file a formal complaint to an independent panel of inquiry, that shall be set-up to handle such complaint." "Where it appears that there are reasonable grounds for making a complaint, the onus will be on the party against whom the complaint of adverse treatment has been made to demonstrate that the actions complained of were not taken in retaliation for the disclosure. ${ }^{18}$ The challenge here is that, by their nature, acts of retaliation are technically outside the purview of the regulation of the law. Hence, this provision appears to have been inadvertently skewed in favor of the party against who a complaint has been made. This approach underscores the urgent call in this part that the government of Nigeria should as quickly as possible adopt a comprehensive legislative framework for the protection of whistleblowers. Where a prima facie case of retaliation is established, "a further investigation may be instituted and disciplinary action may be taken against the perpetrator in accordance with the public service rules/other extant rules and a restitution shall be made to the whistleblower for any loss suffered." ${ }^{19}$ Persons who disclose malicious information may be prosecuted under the law after due investigation that confirms the information provided is false. ${ }^{20}$ To encourage citizens with information to

\footnotetext{
${ }^{13}$ See, Gerry Ferguson, Global Corruption: Law, Theory and Practice, (Second Edition: January 2017, (Chapter 12: "Whistleblower Protections"), pp. 12-2 - 12-48; online: https://icclr.law.ubc.ca/wpcontent/uploads/2017/06/Global-Corruption-Law-Theory-and-Practice-2017-1-1.pdf

${ }^{14}$ Federal Government of Nigeria, Federal Ministry of Finance - Whistle Blowing (FAQs), p. 2

${ }^{15} \mathrm{Ibid}, \mathrm{p} .3$.

${ }^{16}$ Ibid, p. 4

${ }^{17}$ Ibid.

${ }^{18}$ Ibid.

${ }^{19}$ Ibid.

${ }^{20}$ In this regard, a prosecution is already underway for the disclosure of false and malicious information against the Deputy Speaker of the Nigerian House of Representatives, although, it is unclear if the will to prosecute the case has progressed quickly because of the status of the individual wrongly accused. See, Channels Television, "Raid On Ekweremadu's House: Police Arraign Ahmed Echoda Over False
} 
disclose, the program incorporate a reward system for a disclosure the leads to a successful recovery of public funds or assets. In this regard, a whistleblower that provides information which directly leads to the voluntary return of stolen or concealed public funds or assets may be entitled to financial reward between $2.5 \%-5.0 \%$ of the amount recovered. ${ }^{21}$ Although it is early days, the whistleblower program has led to the partial recovery of looted or diverted public funds in Nigeria. ${ }^{22}$

Despite the modest success in recovery of looted public funds, the launch and continued implementation of the FMF-Whistle program without a legislative framework however falls short of the minimum standard of international best practices. In particular, it exposes whistleblowers to a significant level of retaliation or backlash for the disclosure of wrongdoing for public interest. ${ }^{23}$ Without legislative backing, the FMF-Whistle program provides weak and inadequate protection for whistleblowers. It is important to emphasize that the potential implications for public servant whistleblowers may be more compared to ordinary citizens for various reasons. The case of Mr. Ntia Thompson analyzed below illustrates the dilemma of a public servant whistleblower in Nigeria. ${ }^{24}$

Information", May 30 2017, http://www.channelstv.com/2017/05/30/raid-ekweremadus-house-policearraign-ahmed-echoda-false-information/

${ }^{21}$ Federal Government of Nigeria, Federal Ministry of Finance - Whistle Blowing (FAQs), p. 4.

${ }^{22}$ Premium Times, "Whistle-Blower Policy: EFCC Recovers N17billion", April 28, 2017, online: $<$ http://www.premiumtimesng.com/news/top-news/229850-whistle-blower-policy-efcc-recovers n17billion.html >; Taline McPhedran, " $\$ 43 \mathrm{~m}$ in cash found in empty Nigerian apartment", CTV News, April 14, 2017, online: http://www.ctvnews.ca/mobile/business/43m-in-cash-found-in-empty-nigerianapartment-1.3368884

${ }^{23}$ See, Sahara Reporters, "How Whistleblower was Dismissed for Exposing Corruption in Federal Mortgage Bank", Sahara Reporters, New York, June 10, $2017 . \quad$ Online: http://saharareporters.com/2017/06/10/how-whistleblower-was-dismissed-exposing-corruption-federal-

mortgage-bank; also see, Press Release, "Group Demands Reinstatement of Sacked Whistleblowers", Premium Times Newspapers, June 12, 2017. Online: http://www.premiumtimesng.com/news/morenews/233794-group-demands-reinstatement-of-sacked-whistle-blowers.html

${ }^{24}$ This single example should not be taken as a generalization of the practice. It is only a warning of the pitfalls that await a public servant whistleblower in the absence of a protective legislation. The question whether such legislation will be implemented, assuming it exists, is outside the purview of this article.

Other instances of retaliation exist: One Aaron Kaase, a Principal Administrative Officer at the Police Service Commission (PSC). Although the matter predates the adoption of the Whistleblower Policy, it is worth highlighting. On May 22, 2015, he submitted an evidence-based petition to the Independent Corrupt Practices and other Related Offences Commission (ICPC) against the Chairman, Mike Okiro, alleging acts of corruption. Following Kaase's petition against Okiro, the PSC issued a letter backdated to May 21, 2015, suspending him from work indefinitely without pay. They claimed that he was suspended on account of a prima facie case of serious misconduct based on spurious arrest and detention by the police, and arraignment on a fictitious criminal charge. Kaase received no previous query nor was any claim of "serious misconduct" a subject of any investigation that established guilt against him. For more than two years he has remained on suspension without pay while his fundamental rights are continuously violated. The Civil Society Network Against Corruption, CSNAC, has called for the reinstatement of a whistleblower in the Police Service CommissionSee, Oladeinde Olawoyin, "Civil Society organizations call for reinstatement of suspended police whistle-blower", Premium Times Newspapers, March 12, 2017. Online: http://www.premiumtimesng.com/news/more-news/225905-civil-society-organisations-call-reinstatementsuspended-police-whistle-blower.html

The other relates to Mr. Murtala Aliyu Ibrahim, Unit Head/ICT Process Audit and Special Investigation Unit at the Federal Mortgage Bank of Nigeria (FMBN). He had exposed contract scams within the bank and for refused to endorse the bank's 2016 Half-Year Income Validation Report that 
As whistleblowing takes place in different socio-economic, political and cultural contexts; the experience of whistleblowers in the implementation process in one jurisdiction or country cannot be directly compared to experience in a different cultural or legislative context, often at a different time. Complex heterogeneous social networks and informal practices have significant impact on the overall trajectory of a whistleblowing program. These contexts - formal and informal - must be accounted for not only in the design of but also the implementation of the program. I discuss the modalities for understanding the Nigerian informal corruption network in Part II of this article.

\section{Retaliation in the FMF-Whistle Program: The case of Mr. Ntia Thompson}

Mr. Ntia Thompson worked with the Directorate for Technical Cooperation in Africa (DTCA); an agency under the Nigerian Ministry of Foreign Affairs that dismissed him. ${ }^{25}$ In April 2016, Thompson notified the Economic and Financial Crimes Commission (EFCC) of an alleged diversion of funds that were meant for Monitoring Evaluations of Nigeria Technical Cooperation Fund projects by the Acting Director General. The fund was set up in 2004 to undertake projects and programmes capable of contributing to the economic and technological development of regional member countries, to promote regional cooperation and economic integration in Africa. According to him, his dismissal came on the heels of his disclosure of ongoing fraud at the DTCA. Thompson alleged further collusion between the EFCC and the acting Director-General to avoid a refund of any amount. ${ }^{26}$ Although the EFCC recovered some funds from the agency, $\mathrm{Mr}$. Thompson was dismissed from the federal government in February 2017. On their part, the directorate argued that he was relieved of his job after committing infractions under the Public Service Rules and Regulations. ${ }^{27}$ On this basis, the DTCA dismissed the information provided by Thompson to the EFCC as false and a product of bad faith.

basically covers-up the fraud. Instead of addressing the alarm raised by Ibrahim, a memo dated 8 December 2016 signed by the Executive Management Committee transferred him from the head office to a remote location of the FMBN. Hoping to get some immediate redress from the retaliatory action of transferring him and addressing wider corruption within the bank, Mr. Ibrahim petitioned the Minister of Power, Works, and Housing through a series of letters. This effort however proved futile as he was later dismissed from service. Mr. Ibrahim now seeks to challenge his dismissal before a court of law contending that his actions were taken in line with the whistle-blowing policy of the Federal Government. The African Centre for Media \& Information Literacy has called on the Minister for the immediate reinstatement of Mr. Ibrahim. See, Sahara Reporters, "How Whistleblower was Dismissed for Exposing Corruption in Federal Mortgage Bank", Sahara Reporters, New York, June 10, 2017. Online: http://saharareporters.com/2017/06/10/how-whistleblower-was-dismissed-exposing-corruption-federalmortgage-bank

${ }^{25}$ See, Soni Daniel, "Ministry fires whistle-blower who exposed $\$ 229,000$ fraud", The Vanguard Newspapers, March 4, 2017, online: http://www.vanguardngr.com/2017/03/ministry-fires-whistle-blowerexposed-229000-fraud/

26 "Thompson alleged that the acting DG was advised by the EFCC official responsible for the investigation, to, instead of refunding the $\$ 229,000$, undertake trips to countries where projects were executed and bring evidence of travels." Ibid.

${ }^{27}$ See, Abdullateef Salau, Ntia Thompson: Claims, counter claims of dismissed whistle-blower", Daily Trust Newspapers, April 7, 2017, Online: https://www.dailytrust.com.ng/news/general/ntia-thompsonclaims-counter-claims-of-dismissed-whistle-blower/192548.html 
Based on the media uproar that followed Mr. Thompson's dismissal, the Minister of Foreign Affairs restated the Federal Government's commitment to protect any whistleblower that has acted in line with the government's policy, including reinstating Mr. Thompson and paying damages if his appointment was wrongfully terminated. ${ }^{28}$ The process was however not as straightforward as laid out by the Minister in his media response. In June 2017, Mr. Thompson was recalled to service. However, several delay tactics primarily championed by individuals with entrenched interest were adopted to frustrate his eventual return. Based on media reports, the aggrieved top officials of the Federal Ministry of Foreign Affairs engaged in a delay exercise aimed at prolonging his return by forwarding the directive to reinstate him to the Chairman of the Federal Civil Service Commission for advice on whether or not to reinstate Mr. Thompson. Despite repeated calls by the Office of the Head of the Civil Service of the Federation for his reinstatement, ${ }^{29}$ it required the intervention of the Foreign Affairs Minister once more for Mr. Thompson to be recalled eventually. ${ }^{30}$

Although he has been reinstated, Mr. Thompson continues to experience victimization in other forms within the agency. ${ }^{31}$ Various forms of ostracizing, intimidation, and isolation have met his return to the job as the officials alleged of perpetrating the fraud remain in

\footnotetext{
${ }^{28}$ According to the minister, the Federal Government of Nigeria has "a comprehensive report on it and all the issues raised and steps taken...I'm going to look at every aspect of it and if there is a slight, even slightest possibility that there could have been any action that was taken as a result of this person being a whistle blower, I can give you an assurance and guarantee that damages will be paid and the person will be reinstated," - Geofery Onyeama, Ibid. Also see, Business Hilights, "FG ends silence on Ntia Thmpson's Case, assures to protect, reward whistle-blowers", Business Hilights, March 20, 2017, online: http://businesshilights.com.ng/fg-ends-silence-on-ntia-thompsons-case-assures-to-protect-reward-whistleblowers/

${ }^{29}$ See, African Centre for Media \& Information Literacy, "AFRICMIL worried over sack of whistleblower by FMBN, failure to reinstate another by Foreign Affairs Ministry", June 12, 2017, online: http://www.africmil.org/whistle-blowers-under-threat-africmil-worried-over-sack-of-whistle-blower-byfmbn-failure-to-reinstate-another-by-foreign-affairs-ministry/

${ }^{30}$ A letter dates June 20, 2017 with reference No. PSO/C.430/11 recalling Mr. Thompson read as follows: "I am directed to refer to the appeal you forwarded to the Office of the Head of Civil Service of the Federation, OHCSF, in respect of your disengagement from service on the grounds of wrongful suspension, from service for exposing fraud in the Directorate of Technical Cooperation in Africa, DTCA, and to inform you that the Head of the Civil Service of the Federation has approved your appeal for: re-instatement into the service pending the outcome of the investigation into the fraud by the Economic and Financial Crimes Commission. Accordingly, have been reinstated into the service with effect from February 23, 2017. You are, therefore, to report to the Directorate for Technical Cooperation in Africa, DTCA, for further directives..." See, Soni Daniel, "\$229,000 scam: Foreign Ministry recalls whistleblower", Vanguard Nigeria, June 22, 2017, online: http://www.vanguardngr.com/2017/06/229000-scam-foreign-ministry-recallswhistleblower/

31 "Despite his reinstatement, ... the officials involved continued their acts of intimidation and harassment against Mr. Thompson, who was neither restored to his office as directed by the minister, nor his arrears of salary since January 2017 paid to him." See, Bassey Udo, "Nigerian agency celebrate amid lingering corruption allegations", The Premium Times Newspaper, August 1, 2017, online: http://www.premiumtimesng.com/news/top-news/238775-nigerian-agency-celebrates-amid-lingeringcorruption-allegations.html
} 
office. ${ }^{32}$ Despite the recovery of incriminating documents by the investigating agency, no prosecution has commenced. ${ }^{33}$

Although it is doubtful that the retaliation and victimization Mr. Thompson faced and continues to face would be any different if the whistleblower protection law had been passed, his predicament was nonetheless compounded as a result of the lack of whistleblower protection laws. The treatment of Mr. Thompson by the Nigerian civil service provides an ominous warning to other public servants with valuable public interest information. Faced with a choice of retaliation and silence, many public service employees may decide not to disclose any information. Such decisions to be silent in the face of corrupt actions are symptomatic of embedded informal social norms of corruption.

The plight of Mr. Thompson illustrates the challenge associated with viewing formal whistleblower protection laws as absolute, definitive, and a sine qua non to effectiveness or indeed antidote to corruption. More importantly, it demonstrates the urgent need to rethink the design of the laws for the FMF-Whistle program in the public service in order to better align it to simultaneously address the embedded informal social norms that aid corruption in the system as well as the protection of the whistleblower. While it reinforces the case for an urgent adoption of such a legislation, it also demonstrates the potential limitation of formal whistleblowing laws in the absence of political will to address informal social networks and embedded values in relation to the social acceptability of corruption. In short, it provides a litmus test for the complexity of the formal and informal mechanisms that are required to effectively implement whistleblowing in Nigeria.

Additionally, unequal power relations between top officials' accused of corruption in the government agency and Mr. Thompson also present an aspect of the potential complexity associated with cases of whistleblowers who are public servants vi-a-vis those alleged to have completed the corrupt act. The unequal power relations between whistleblowers and public governance mechanisms or their senior colleagues, against which allegations are made, require the governing framework to be especially strong and effective so that it may create a meaningful safe alternative to silence and retaliation for the whistleblower. In the concluding section of Part I, I analyze the significance of the legislative framework for the protection of whistleblowers for the long-term institutionalization and cooperation of the stakeholders.

\section{Adopting Whistleblower Protection Law: A Minimum Requirement}

A critical element of international best practices on whistleblower programs is the existence of whistleblower protection laws. ${ }^{34}$ It is important to note that whistleblowers

\footnotetext{
${ }^{32}$ See, Cletus Ukpong, "Nigerian govt pledges to review cases of citizens punished for exposing corruption", Premium Times Newspapers, March 19, 2017, online: http://www.premiumtimesng.com/news/top-news/226534-nigerian-govt-pledges-review-cases-citizenspunished-exposing-corruption.html

${ }^{33}$ Ibid.
} 
enjoy some protections under various individual legislations in Nigeria, however, the provisions are far from as comprehensive as they should be. A significant flaw of the existing protection is that they are skewed in favour non-disclosure of identity as opposed to protection from retaliation.

Certain universal features distinguish whistleblower protection legislations, to wit; guarantees effective enforcement mechanisms for the rights and remedies of the whistleblowers; facilitates public awareness and education about whistleblowing; and it comprehensively provides for protection of those who, in good faith and on reasonable grounds, speak out against suspected acts of wrongdoing. ${ }^{35}$ The advantages of such laws are critical because of the significant consequences and risks that whistleblowers face due to power imbalances. ${ }^{36}$ Viewed as a process, "whistleblowing necessitates laws or policies that provide a clear description (1) of what types of perceived wrongdoing should be disclosed, (2) to whom such disclosures should be made initially and subsequently (if the initial disclosure does not prompt an investigation), (3) how and by whom the alleged wrongdoing should be investigated, (4) the mechanisms and procedures that are in place to encourage persons to disclose wrongdoing while protecting the whistleblower from any disciplinary action or adverse consequence for reporting the wrongdoing, and (5) the steps to be taken if adverse consequences are, or appear to be, imposed on the whistleblower." 37

Whistleblower protection laws reassure potential whistleblowers of their potential rights and protection against retaliation. Retaliation or backlash for whistleblowing may take various forms that include but are not limited to outright termination or suspension of employment to others such as ostracism, character defamation, harassment, demotion, work overload, poor performance appraisals, denial of promotion, disciplinary actions, and transfers to area offices that may potentially mean that the employee is redundant and left frustrated. ${ }^{38}$ Although the risks associated with whistleblowing for the whistleblower are minimally curtailed where a comprehensive and effectively implemented legal

${ }^{34}$ See, Transparency International, "Strengthening Whistleblower Protection: An International Imperative", 7 June, 2013; https://www.transparency.org/news/feature/strengthening_whistleblower_protection_an_international_imp erative;

${ }^{35}$ See generally, Transparency International, International Principles for Whistleblowing Legislation, (November 2013); Mark Worth, "Whistleblowing in Europe: Legal Protections for Whistleblowers in the EU", (2013: Transparency International); Council of Europe, "Protection of Whistleblowers: A Brief Guide for Implementing a National Framework", August 2016, pp. 1-26.

${ }^{36}$ Marcia P. Miceli, "An International Comparison of the Incidence of Public Sector Whistle-Blowing and the Prediction of Retaliation: Australia, Norway, and the US", (2013) 72:4 Australian Journal of Public Administration, pp. 433-446.

${ }^{37}$ Ferguson, supra note 13, p. 12-3.

${ }^{38}$ Gregory Liyanarachchi and Chris Newdick, "The Impact of Moral Reasoning and Retaliation on Whistleblowing: New Zealand Evidence", (2009) Vol. 89:1, Journal of Business Ethics, pp. 37-57; Greenberger, D.B., Miceli, M.P., \& Cohen, D. "Oppositions and group norms: The reciprocal influence of whistle-blowers and co-workers", (1987) 7Journal of Business Ethics, pp. 527-542; Miceli, M.P., \& Near, J.P. "Relationships among value congruence, perceived victimization, and retaliation against whistle-blowers" (1994) 20 Journal of Management, pp. 773-794. 
framework exits; the lack thereof, particularly in Nigeria with embedded corrupt practices in the public governance, exacerbates the risks for the whistleblower.

To strengthen the legal, policy and regulatory framework for the anti-corruption agencies, the NACS recommends the "enactment/strengthening of specific laws on pleabargaining, whistle-blower and witness protection, and non-conviction based asset forfeiture." ${ }^{39}$ In particular, it recommends that the Economic and Financial Crimes Commission (EFCC) "develop a robust whistleblower policy including mechanisms for whistleblower confidentiality and protections" while the National Assembly should expedite the passage of the Whistleblower Protection Bill. ${ }^{40}$ To increase public support and citizen's ownership of the fight against corruption, within one year, the NACS will "identify and strengthen the existing protections offered by the various relevant laws to cover whistle-blowers." ${ }^{41}$ While the government has publicized the progress made in relation to non-conviction based asset recovery and forfeiture, tangible progress has not be made in relation to the adoption of a comprehensive whistleblower protection law.

At the moment, there are five (5) different bills at various stages of legislative process before the Nigerian National Assembly. ${ }^{42}$ An important step would be to consolidate these bills into one comprehensive whistleblower protection law that reflects the features of the international best practices on whistleblowing. The adoption of such international

\footnotetext{
${ }^{39}$ Nigerian National Anti-Corruption Strategy, p. 19

${ }^{40}$ Ibid, pp. 15 and 18.

${ }^{41}$ Ibid, p. 27; For the Nigerian government's secure online portal through which information bordering on violation of financial regulations, mismanagement of public funds and assets, financial malpractice or fraud and theft that is deemed to be in the interest of the public can be disclosed, see, Federal Ministry of Finance Whistleblowing Portal, online: http://whistle.finance.gov.ng/Pages/default.aspx.

${ }^{42}$ These bills include: The Public Interest Disclosure Bill 2015, HB 03, is currently under consideration by the Nigerian House of Representatives. It was first introduced on 28 July 2015 and on same day it passed the First Reading. On 15 December 2015, it passed the second reading and two years later, the House Committee on Justice provided its report on the Bill to the House on 26 January 2017. No further action known to the author has since been reported on the Bill. (Copy on file with the author)

The Public Interest Disclosure Bill 2015, HB 03, is currently under consideration by the Nigerian House of Representatives. It was first introduced on 28 July 2015 and on same day it passed the First Reading. On 15 December 2015, it passed the second reading and two years later, the House Committee on Justice provided its report on the Bill to the House on 26 January 2017. No further action known to the author has since been reported on the Bill. (Copy on file with the author)

The Witness Protection Programme Bill 2015, HB 132, is also before the Nigerian House of Representatives. It was first introduced on 25 November 2015, and has since under First and Second Reading respectively on 25 November 2015 and 23 February 2016, and was passed by the lower House on 7 June 2016. While it appears the Bill was introduced into the Nigerian Senate on 11 October 2016, no further activity has been reported on the Bill. (Copy on file with the author)

This second Witness Protection Programme Bill 2015, SB 157 was introduced in the Nigerian Senate on 8 December 2015. It differs in substance from the version introduced in the lower house and has gone through Second Reading on 19 October 2016 with eventual passage on 8 June 2017. The Bill is yet to be introduced to the House of Representatives for consideration. (Copy on file with the author)

The Whistle Blowers Protection Bill, 2016, SB 158 was also first introduced in the senate on 15 March 2016. It passed Second Reading 19 October 2016 with eventual passage by the Senate on 8 June 2017. The Bill is yet to be introduced to the House of Representatives too. (Copy on file with the author)

The Whistle Blower Protection Bill 2017, HB 1073, was first introduced before the House of Representatives on July 12 2017. It has not gone beyond the First reading.
} 
best practices will constitute a minimum standard in addition to which informal anticorruption governance strategies must be developed to address the embedded nature and social acceptability of corruption in the Nigerian public service and the society at large. ${ }^{43}$ When passed into law, where effectively implemented in a neutral and non-selective manner, whistleblower protection laws may also limit the potential "chilling effect" that may otherwise be associated with such a regime in Nigeria where there is an overwhelming distrust of the rule of law and judiciary in bringing to justice the highprofile perpetrators of corruption. Its implementation must however be backed by unequivocal political will, independence in investigative process, and confidentiality of the identity of the whistleblower. The legislation should also provide for a trustworthy chain of disclosure open to receiving complaints and must offer a safe alternative to silence.

It is however important to caution that the suggestion here is not to repeat the uncritical and disproportionate focus on formal legal frameworks that characterizes traditional anticorruption policies. For to suggest a purely legalistic approach would be to inevitably reinforce and enable the space for manoeuvring the law to be manipulated in service of corrupt practices. Often neglected in prescriptions for the adoption of new laws are the role of power dynamics; the elitist social structures in Nigeria; informal networks of corruption in public service; and the partial social acceptability of corruption. The redistribution of the proceeds of corruption through the informal networks of corruption compounds the reach of formal anti-corruption mechanisms like whistleblowing.

As important as whistleblower protection laws and the complementary role of existing anti-corruption institutions are to the effectiveness of the implementation of the anticorruption program, the factors that encourage corruption are an outcome of a complex mixture of embedded informal and formal "local, regional, and global factors and reflect many layers of oppression working together. Such complex problems are hardly capable of being resolved [solely] through technocratic interventions; in fact, such interventions may exacerbate the level of corruption." 44 As, Balakrishnan Rajagopal opines, "attempts to tackle corruption should be based on the concrete problems and deprivations of the victims of corruption in particular local situations, rather than on a grand global strategy of anti-corruption that only results in increasing the sphere of activity of the states and international organizations." 45

In Part II, I provide an example of a conceptual lens for understanding informal social networks of corruption in Nigerian public service. The point is that paying attention to these informal networks of governance and addressing them to the extent possible would enhance the effectiveness of not only the FMF-Whistle program but also the overall anticorruption program in Nigeria.

\footnotetext{
${ }^{43}$ David Banisar, "Whistleblowing: International Standards and Developments" in Irma E Sandoval, ed, Contemporary Debates on Corruption and Transparency: Rethinking State, Market, and Society (Washington, DC: World Bank, Institute for Social Research, UNAM, 2011)

${ }^{44}$ Rajagopal, "Corruption, Legitimacy and Human Rights: The Dialectic of the Relationship", p. 505.

${ }^{45}$ Ibid, p. 507
} 


\section{Part II}

\section{Co-Optation, Control, and Camouflage: A Lens for Understanding the Modalities of Informal Corruption in Nigerian Public Governance}

Intangible or informal social factors assume a much more critical importance in developing countries like Nigeria with a high level of poverty; poor record of public service remuneration; and historically entrenched corrupt practices. ${ }^{46}$ Social preferences, informal social norms, social identities and social networks exert significant influence on the decisions and actions of public servants and citizens in general. ${ }^{47}$ Social norms are "embedded markers of how people behave as members of a society and have strong influence on how they chose to act in different situations. Social influences determine accepted forms of behavior in a society, and act as indicators of what actions are appropriate and morally sound or disapproved of and forbidden." 48

Public governance and public service is a microcosm of the wider social complex in Nigeria. To be effective, the FMF-Whistle Program needs to take account of the patterns of informality that encourage and sustain high levels of corruption. To illustrate how informal corruption works in the Nigerian public service, I draw on the recent work of Claudia Baez-Camargo and Alena Ledeneva. ${ }^{49}$ For them, "acknowledging the functionality of informal practices goes a long way in accounting for [the resilience of informal networks of corruption]." 50 Informal norms and practices of corruption are resilient, not only because of culture, but also because they perform critical functions from which the political elites, public servants, private interests and ordinary citizens all benefit. $^{51}$

Baez-Camargo and Ledeneva identify three distinct forms of informal governance that cut across the public-private divide: co-optation, control, and camouflage. ${ }^{52}$ These

\footnotetext{
${ }^{46}$ The World Bank defines social accountability as "the broad range of actions and mechanisms beyond voting that citizens can use to hold the state to account, as well as actions on the part of government, civil society, media and other societal actors that promote or facilitate these efforts" See, World Bank, Social Accountability: What does it mean for the World Bank? in Social Accountability Sourcebook, (2006, World Bank, Washington D.C.), p. 5

${ }^{47}$ J.P. Olivier de Sardan, “A Moral Economy of Corruption in Africa?", (1999) 37:1 The Journal of Modern African Studies, pp. 25-52.

${ }^{48}$ Leena Koni Hoffmann and Raj Navanit Patel, "Collective Action on Corruption in Nigeria"; also see, Bicchieri, C. and Mercier, H. (2014), 'Norms and beliefs: how change occurs', in Xenitidou, M. and Edmonds, B. (eds), The Complexity of Social Norms, (2014; Cham: Springer International Publishing), pp. $37-54$.

${ }^{49}$ See, Claudia Baez-Camargo and Alena Ledeneva, "Where Does Informality Stop and Corruption Begin? Informal Governance and the Public/Private Crossover in Mexico, Russia and Tanzania", (2017) Vol. 95, No. 1, The Slavonic and East European Review, (Innovations in Corruption Studies), pp. 49-75. According to the authors, "in spite of cultural, historical and regional diversity, the three countries ... share a characteristic that is stubbornly persistent outside of the developed world: the failure to control corruption notwithstanding the adoption of exemplary legal frameworks that incorporate many of the internationally recognized best anti-corruption practices." P. 51.

${ }^{50}$ Ibid, p. 50.

${ }^{51}$ Ibid, p. 52.

52 Ibid.
} 
patterns of informal governance sustain, protect, and discipline any actors involved in the network. Whereas co-optation ${ }^{53}$ is associated with the strategic employment, promotion, or filling of public office appointments with potential allies or members of the informal networks of governance that are disposed to ensuring the continuation of the exploitation of public power and resources, ${ }^{54}$ control, refers to unwritten techniques, such as selective enforcement of anti-corruption laws against opponents, by which the powerful informal networks discipline dissidents thereby ensuring they keep the support of the citizens. ${ }^{55}$ While the formal anti-corruption enforcement mechanism is deployed in executing these decisions, in reality, they are a calculated choice by the party in power to ensure control of the system. Camouflage refers to the methods by which political co-optation and control are covered up through the use of institutional facades. As Baez-Camargo and Ledeneva, "formal constraints are essential for the effectiveness of informal practices ... the formal rules and institutions of the public sector (the façade) are sustained in order to manipulate, undercut, divert or exploit for the sake of informal interests." 56 In particular, co-opted allies in the law enforcement sector selectively apply the laws or simply fail to diligently prosecute the high-profile corruption cases that are brought to court. Through camouflage, the party in power disguises the punishment of an opponent, dissident member of informal network, or potential whistleblower based on the existing formal structures of anti-corruption.

A crucial aspect of informality in confronting corruption through whistleblowing in the Nigerian public service relates to the social acceptability of corruption and community norms. Behaviours that would otherwise qualify as corrupt is justified on the basis that they benefit "one's own people." 57 Critical to the public and private sector overlap of these informal networks of corruption is the notion that any member successfully coopted into public office positions has an unwritten duty to utilize the position for the benefit of the network. This practice reinforces the social acceptability of corruption as it serves the important role of sustaining the elitist lifestyle of its members. There is therefore an inherent disparity in the regulation of what is socially acceptable vis-à-vis what is formally condemnable because what is socially acceptable is "articulated in a continual and fluid evaluation of the particular circumstances surrounding each act rather than on rigid standards of ethical behaviour stemming from a clear distinction between the public and private realms". 58

\footnotetext{
${ }^{53}$ For various iterations of the concept of co-optation is social sciences scholarship, see, P. Selznick, "Foundations of the Theory of Organization" (1948) 13:1 American Sociological Review, pp. 25-35; G. Bertocchi and M. Spagat, "The politics of Co-optation", (2001) 29 Journal of Comparative Economics, pp. 591-607; Patrick G. Coy, "Co-optation", The Wiley-Blackwell Encyclopedia of Social and Political Movements, (1993), pp.

${ }^{54}$ Claudia Baez-Camargo and Alena Ledeneva, supra note 50, p. 53. "The criteria for such recruitment and the non-transparency of the redistribution are both linked to corrupt behaviours."

${ }^{55}$ Ibid, p. 62

${ }^{56}$ Baez-Camargo and Ledeneva, supra note 50, p. 68.

${ }^{57}$ Claudia Baez-Camargo and Nikos Passas, "Hidden agendas, social norms and why we need to re-think anti-corruption", 2017 OECD Global Anti-Corruption \& Integrity Forum, pp 5-6. Online: https://www.oecd.org/cleangovbiz/Integrity-Forum-2017-Baez\%20Camargo-Passas-hidden-agendassocial-norms.pdf

${ }^{58}$ Ibid.
} 
Hitherto, the anti-corruption graft in Nigeria has not explicitly given consideration to these ethical and moral questions relating to the reciprocity of favour and mutual assistance to "one's own people" simply by virtue of being in public office. ${ }^{59}$ Yet, informal practices of co-optation, control and camouflage are pungent and meaningfully shape the interactions "among power networks of political and business elites and [also] influence how state actors relate to the general public." ${ }^{\circ 0}$ In addition, they sustain the survival and promotion of elite interests while simultaneously weakening opponents. Although considerations about addressing the overlap of the social acceptability of corruption and community norms at large have been outside the purview of the formal legal framework of anti-corruption, the introduction of whistleblowing provides a unique opportunity to articulate ways by which the government can incorporate informal techniques of anti-corruption that simultaneously address these underpinning factors that encourage corruption.

While more empirical research will be required to document the veracity of informal networks of corruption in Nigeria, the foregoing analyses demonstrate that, understanding the role of co-optation, control and camouflage provide a useful lens for understanding informal corrupt actions in public governance in Nigeria. The majority of the high-profile corruption scandals in Nigeria that have been associated with the diversion of public funds have primarily been facilitated through embedded networks of informality. These networks build overtime through co-optation, and controlled through the various techniques of promotion and appointments of allies, have contributed significantly to the successful camouflage of scandalous looting in public governance in Nigeria. The network agents masterfully exploit the disparity between formal and the informal by camouflaging their activities under the legal order of anti-corruption. In the context of whistleblowing in particular, it is imperative that the Nigerian government proactively incorporates possible strategies to demystify the informal corruption networks that otherwise enhance and jeopardize corruption and anti-corruption mechanisms respectfully.

In Part III, I conclude by examining some practical formal and informal steps that the government might adopt in enhancing whistleblowing as a panacea for anti-corruption graft in Nigeria.

\footnotetext{
${ }^{59}$ I am aware that political scientists have addressed this question in the context of "clientelism" and "belly-politics" in Africa. See, Jean-Francois Bayart, The State in Africa: The Politics of the Belly, (London and New York, Longman, 1993). However, I have deliberately framed the analysis different in other to open up new paths of analysis to interrogate the complex issue of corruption that is not bound to end in doom or outright failure.

${ }^{60}$ Baez-Camargo and Passas, supra note 58, p. 3.
} 


\section{Part III}

\section{Towards a Transformative Governance Framework for Whistleblowing in Nigeria}

In the majority of the legal frameworks aimed at addressing the menace of corruption, socio-political informal networks of co-optation, control and camouflage, and their potential to illuminate the discourses of anti-corruption in public governance as with all levels of society, have not been adequately captured or accounted for. Recent research work is however gradually challenging the dominance of the purely legalistic and formal approach to anti-corruption by emphasizing the role of the informal and social norms. ${ }^{61}$ As Claudia Baez Camargo and Nikos Passas argue, corruption “... enjoys social acceptability especially when [it is] effective in solving practical problems and protecting livelihoods. The functional relevance of informal practices clarifies the factors behind the limited effectiveness of anti-corruption law-driven reforms, short-term action plans, and technical measures that focus on particular processes, procedures and institutions." ${ }^{\prime 62}$

Effectively addressing corruption in public governance in Nigeria through whistleblowing must therefore not carve-out the public service as distinct and separable from the wider society. Situated in the broader socio-political context and overall anticorruption war in Nigeria, the introduction of the whistleblowing program offers a unique opportunity to rethink and reformulate the approaches to anti-corruption in Nigeria. ${ }^{63}$ In the following sections of this article, I provide two examples of complementary practical informal steps that can be harnessed to support the formal anticorruption structures generally, and whistleblowing in particular. It is important to reiterate that these measures are in addition to those provided in the NACS.

\footnotetext{
${ }^{61}$ Since 2015, a series of empirical multi-disciplinary research projects funded by The British Academy currently examine various aspects of informal governance both in the context of corruption, collective action and public service more broadly. For a list of the projects, see, BA/DFID Anti-Corruption Evidence Partnership, https://www.britac.ac.uk/node/3584. In particular, see, Claudia Baez Camargo, Alena Ledeneva, and Scott Newton, "Informal Governance and Corruption - Transcending the Principal Agent and Collective Action"; This "multidisciplinary research team combines unique regional expertise and practical experience in order to produce evidence for the relevance of informality for the 'localisation' of anticorruption strategies, thus enhancing their impact, and for a new generation of policies harnessing the potential of local patterns of informality." Online: https://www.britac.ac.uk/node/4660. Also see, Gerhard Anders, Jean-Pierre Olivier de Sardan, and Giorgio Blundo, "Accountability through Practical Norms: Civil Service Reform in Africa from Below", The project, presently in its second year, explores "ways to improve service delivery and levels of integrity by drawing on empirical evidence on practical informal norms in key government departments (health and education) in Sierra Leone, Senegal, Togo, Niger, Tanzania and Malawi. It will be the first comparative, cross-country study employing anthropological and socio-legal methods at a large scale to generate systematic empirical evidence on practical norms covering francophone and Anglophone countries in two regions, West and East Africa". See, https://www.britac.ac.uk/node/3525/;

${ }^{62}$ See, Claudia Baez Camargo and Nikos Passas, supra note 58.

${ }^{63}$ See, Leena Koni Hoffmann and Raj Navanit Patel, "Collective Action on Corruption in Nigeria: A Social Norms Approach to Connecting Society and Institutions"
} 
Formal and Informal Education aimed at Raising awareness on ills and rejection of Corrupt Behaviors

A proactive stakeholder engagement is critical to the effectiveness of any whistleblower policy. ${ }^{64}$ Formal and informal education about whistleblowing has a significant role to play in the effectiveness of the whistleblowing program in Nigeria. ${ }^{65}$ One way that the Nigerian whistleblower policy serves as a formal policy with potential for success is that it's reward mechanism is closer to social norms and practices of the Nigerian society. ${ }^{66}$ It is important for the government at the federal, state and local levels to introduce formal and informal educational and awareness programs that promote "expectations, values and mental models consistent with the rejection of corrupt behaviors."

The Nigerian government could draw inspiration from the Rwandan regime where their program sought to promote integrity as a value associated with the national identity by developing traditional culturally oriented training programs across different educational strata that are aimed at inculcating appropriate values in the citizens. ${ }^{68}$ Ethos of "naming and shaming" as opposed to celebration of illicitly acquired wealth from public resources must be encouraged through these educational programs. The advantage of adopting such informal educational tools and training is that it addresses some of the gap between formal rules and informal practices of corruption analyzed in this paper. ${ }^{69}$ In this regard, the NACS promotes ethical orientation for improved personal ethics and ethical conduct in nation building, which will guide citizens. The average Nigerian has a significant level of distrust in the government and its commitment to anti-corruption. To truly make the whistleblower program a citizen oriented and driven one as anticipated in the NACS, it is important that Nigerians are not only effectively sensitized to own a part of the crusade, but also, that the government demonstrates unequivocally its transparency in dealing with corrupt officials that are reported. ${ }^{70}$

\section{Transparency in the Redistribution of Voluntary Asset Recovery}

Another practice that can strengthen the whistleblowing program in Nigeria is greater transparency by the government, particularly in relation to the expenditure of funds

\footnotetext{
${ }^{64}$ See, Bill Libit, "Elements of an Effective Whistleblower Hotline", Harvard Law School Forum on Corporate Governance and Financial Regulation, Saturday, October 25, 2014, https://corpgov.law.harvard.edu/2014/10/25/elements-of-an-effective-whistleblower-hotline/

${ }^{65}$ James Gerard Caillier, "An examination of the role whistle-blowing education plays in the whistleblowing process", (2017) 54 The Social Science Journal, pp. 4-12., p. 5

${ }^{66}$ The modest success that the program has enjoyed since its introduction attests to this fact.

${ }^{67}$ See, Claudia Baez Camargo and Nikos Passas, "Hidden agendas, social norms and why we need to rethink anti-corruption", supra note 58.

${ }^{68}$ Ibid.

${ }^{69}$ For empirical studies on the link between whistleblowing education and whistleblowing intentions, see, Cho, Y. J., \& Song, H. J., "Determinants of whistleblowing within government agencies" (2015) 44:4 Public Personnel Management, pp. 450-472.

${ }^{70}$ See, Ayo Sogunro, "Why whistle-blowing won't save Nigeria”, African Arguments, May 4, 2017, online: http://africanarguments.org/2017/05/04/whistle-blowing-wont-save-nigeria/
} 
recovered from past looting based on information from whistleblowers. ${ }^{71}$ Successive administrations in Nigeria have been modestly successful in the recovery of looted funds and assets. However, the secrecy that surrounds the redistribution of such funds for public use, either through budgeting for physical infrastructure or otherwise, make them susceptible to allegations of further embezzlement. In the context of whistleblowing, government can avoid camouflaging, build wider citizen trust and improve participation in the whistleblowing program through adequate publication of amounts recovered as well as how these amounts are reinvested for the common good of the citizenry. The goal is to demonstrate convincingly that the recovered funds have simply not been re-looted.

\section{Conclusion}

The core argument made in this paper is that the effectiveness of the whistleblowing program in Nigeria is dependent on the recognition of the complementary functionality of the informal corruption networks in public service and the Nigeria in general. Therefore, an approach that is based solely on the formal aspect misses a significant lever in relation to the informal social practices of corruption that are embedded in society. From this perspective, merely adopting and implementing the most comprehensive legislation for the protection of whistleblowers, while important, is insufficient to address the root causes of wrongdoing in public governance. While an adequate and complete legal regime is urgently required for the protection of whistleblowers and to guard against retaliation, simply responding by tougher formal laws would not be enough. It must be supplemented with multi-faceted approach across social and cultural aspects that address the embeddedness of corruption. Therefore, if the whistleblower program is aiming not suffer the same fate as previous anti-corruption mechanisms, its implementation and design must take significant account of the local context and informal practices that privilege corruption in public governance and the society at large. Laws do not exist in abstract; rather, they are intricately intertwined with the social structures of the societies that adopt them. It is therefore important to account for the informal social norms in the design and implementation of a whistleblowing regime. The NACS already anticipates this holistic approach to dealing with the social and informal aspects of corruption; the government must now follow this aspiration with concrete actions. In addition to the government, faith institutions and non-governmental organizations have important roles to play in both the education of the citizenry and cultivating trust in the government's policies.

\footnotetext{
${ }^{71}$ Transparency International Secretariat, "Nigeria must strengthen Anti-Corruption Bodies and Increase Transparency on Asset Recovery", Transparency international, June 16, 2016; Online: https://www.transparency.org/news/pressrelease/nigerian_must_strenghthen_anti_corruption_bodies_and_i ncrease transparency
} 